\title{
Performative læringsrum på digitale scener - dramadidaktik og sociale medier
}

\author{
Kristian Nødtvedt Knudsen`, \\ NTNU, Trondheim, Norge
}

\section{Sammendrag}

Skolens læringsrum er udfordret gennem de sociale mediers konstante tilstedeværelse. Det kan være vanskeligt for lærere at håndtere, hvordan de sociale og digitale rum kan integreres i undervisningen. Hensigten med denne studien er at undersøge, hvordan performative læringsrum opstår i mødet mellem dramadidaktik og sociale medier. Studien tager udgangspunkt i et undervisningsforløb, som blev designet og gennemført af forfatteren i løbet af efteråret 2015 med 89 gymnasieelever fra første til tredje klasse i Trondheim. Forløbet tager udgangspunkt i to hovedspørgsmål: Hvem er du på de sociale medier og Hvordan lever du med de sociale medier? Inspirationen til udviklingen af forløbet hentes fra et senmoderne og performativt syn på subjekt og erkendelse. I artiklen redegøres for de dramaturgiske principper som er tilstede i forløbet og efterfølgende bringes den dramaturgiske tænkning med ind $\mathrm{i}$ analysen af undervisningsforløbet. Afslutningsvis tegnes konturerne af de performative læringsrum, som opstår i krydsfeltet mellem dramadidaktik og sociale medier. Betegnelsen performative læringsrum er ikke et etableret begreb hverken i en dramadidaktisk eller kunstpædagogisk kontekst. Studien skal således også ses som et forsøg på at definere en sådan betegnelse.

\section{Nøkkelord: Dramaturgi; dramadidaktik; performativitet; sociale medier; uddannelse}

\begin{abstract}
The constant presence of Social Media has left its mark on schools and other educational institutions. It can be a challenge for the teacher to find ways to integrate the social and digital spaces in an educational context. In this study, I explore how performative learningspaces arise in the crossover between teaching and learning drama and social media. The study uses data from a workshop designed and implemented by the author with 89 high school students from Trondheim in the autumn of 2015. In the workshop, I try to implement a performative and postmodern view on the subject and on knowledge production. The article discusses the dramaturgical principles that are present in the workshop and utilizes the dramaturgical thinking as an analytical tool in the inquiry of the performative learning spaces. In conclusion, I discuss what performative learning spaces can bring to drama in education and education in genereal. The term "performative
\end{abstract}

^Korrespondanse to: Kristian Nødtvedt Knudsen, NTNU - Program for lærerutdanning, 7491 Trondheim, Norge. E-mail: Kristian.knudsen@ntnu.no 
learning spaces" is not an established concept neither in teaching and learning drama or in arts in education. The study should thus be seen as an attempt to define such a concept.

Keywords: Dramaturgy; the performative turn; education; teaching and learning drama; social media

Received: August 2016; Accepted: September 2016; Published: January 2017

\section{Performative læringsrum på digitale scener - dramadidaktik og sociale medier}

Det følgende tager udgangspunkt $\mathrm{i}$ et konkret undervisningsforløb, som blev gennemført i løbet af efteråret 2015 med 89 gymnasieelever fra første til tredje klasse i Trondheim. Forløbet hedder \#ilive og er designet og gennemført af undertegnede. Undervisningsforløbet varer cirka tre timer og tager udgangspunkt i to hovedsprgsmål; Hvem er du på de sociale medier? Hvordan lever du med sociale medier? Hensigten med denne studie er at undersøge, hvordan performative læringsrum opstår i mødet mellem dramadidaktik og sociale medier. Betegnelsen performative leringsrum er ikke et etableret begreb hverken i en dramadidaktisk eller kunstpædagogisk kontekst. Studien skal således også ses som et forsøg på at definere en sådan betegnelse. I artiklen redegør jeg først for den forforståelse, som ligger til grund for udviklingen af forløbet og de dramaturgiske principper, som er tilstede i \#ilive. Efterfølgende bringes den dramaturgiske tænkning med ind i analysen af undervisningsforløbet, og afslutningsvis tegnes konturerne af de performative læringsrum, som opstår i krydsfeltet mellem dramadidaktik og sociale medier.

\section{Drama i det performative samfund}

I sin introduktion til The Radical in Performance: between Brecht and Baudrillard (1999) skriver Baz Kershaw, at performancegenren har overtaget teatrets funktion som samfundskritisk kommentator og som en central aktør i en globaliseret og medieret verden. Ifølge Kershaw er performance, særligt uden for teatrets mure, et energisk felt, hvor man kan tage fat på den kompleksitet, som eksisterer i et postmoderne samfund (Kershaw, 1999, s. 7). I den postmoderne tænkning ligger der et opgør med det modernes tanke om en fast identitet, et autonomt subjekt og en forestilling om, at der findes noget bedre. Postmodernismens ideal om en fragmenteret helhed og et decentreret subjekt stemmer godt overens med den performative vendings intention om at flytte fokus fra teksten, som forestillingens dominerende omdrejningspunkt, til et større fokus på kropslige udtryk og en emergent æstetik (jf. Fischer-Lichte, 2008; 2014). Ifølge Tor Helge Allern er en senmoderne opfattelse af performance ikke

\footnotetext{
${ }^{1}$ Ligesom Allern støtter jeg mig også til betegnelsen senmoderne fremfor post-moderne. Begrebet sen-moderne nedjusterer det lineære aspekt om noget er før og efter og peger både på kontinuitet i forhold til det moderne, samt at der opstår nye samfundsmæssige tilstande og muligheder for udvikling af individualitet og erkendelse (Allern, 2003, s. 312).
} 
specielt knyttet til teatret (Allern 2003, s. 314). ${ }^{1}$ Enhver hændelse, som er bevidst det performative, når den gennem en fremførelse gør sin egen handling fuldstændig, kan beskrives som performance. Hændelsen transformeres til en selv-refleksiv handling (Allern 2003, s. 314). Allern udvider performancegenrens spillerum fra at have tilhørt teatret eller en kunstverden, til også at blive inkluderet som et væsentligt aspekt ved det samfund vi lever i, herunder også skolen. Udvidelsen af spillerummet medfører dog også didaktiske udfordringer, særligt med tanke på dramafagets traditionelle fokus på fiktion og fiktionskontrakt.

I artiklen "Person og rolle" (2011) foretager Janek Szatkowski en lignende manøvre, da han tager fat i preformativitetsbegrebet med udgangspunkt i det, han beskriver som samtidens videnssamfund. ${ }^{2}$ Kendetegnende for videnssamfundet er, at rollen som arbejdstager forgrener sig langt ind i privatlivet og fordrer, at hele personligheden engagerer sig i virksomhedens daglige arbejde (Szatkowski, 2011, s. 11). Szatkowski foretager et kritisk eksperiment med udgangspunkt $\mathrm{i}$ et systemteoretisk perspektiv. Han anvender distinktionen mellem person og rolle til at undersøge, hvordan performativitet kan beskrive enkeltindividet og gruppers kommunikation, samt hvordan den etableres. Szatkowski henviser til Niklas Luhmanns Sociale systemer (1984), som definerer rollen som værende adskilt fra personen. Bag personen er der et program, og bag programmet er der nogle vecrdier. Ifølge Szatkowski så er det først, når denne skelnen mellem person og rolle er indført, at det giver mening, at det enkelte menneske kan identificere sig som person og samtidig orientere sig i forhold til forskellige roller:

Rollen relaterer altså til det enkelte menneske, men også til det forhold, at en rolle kan udføres af mange og principielt udskiftelige personer: lærerrollen, en plejerrolle osv. Man kan forstå rollen som en måde at reducere kompleksitet på. Rollen vejleder adfærd på en sådan måde, at man er sikret social accept, hvis man følger dens program, og samtidig garanterer rollen også, at man med stor sikkerhed kan forvente en bestemt adfærd af den, der udfører den (Szatkowski, 2011, s. 114-115).

Det er ikke min intention at bringe den Luhmannske systemteoretiske konstruktivisme med ind i denne studie. En sådan manøvre ville ikke stemme overens med studiens fokus på hvordan performative læringsrum opstår i mødet mellem dramadidaktik og sociale medier. ${ }^{3}$ Men Szatkowskis måde at operere med systemet på åbner op for at reducere den kompleksitet, rolle-og persondistinktionen ellers indeholder $i$ en performativ kontekst. At en rolle kan udføres af mange, samt vejlede adfærd er interessante betragtninger at bringe med ind $\mathrm{i}$ en udforskning af de sociale medier. Beskrivelsen af arbejdstagerne i videnssamfundet kan adapteres til dagens unge

\footnotetext{
${ }^{2}$ Det skal siges, at Allern og Szatkowski anvender performativitetsbegrebet ud fra forskellige betydninger. Allerns beskrivelse af begrebet kan placeres indenfor en sproglig og sociologisk tradition (Jf. Austin, 1992 og Butler, 1999). Szatkowski understreger, at hans bestemmelse af begrebet ikke hviler på en lingvistisk analyse af sprog/skrift/tale, men en dramaturgisk analyse af den menneskelige kommunikation.

${ }^{3}$ For en grundigere indføring $\mathrm{i}$ et systemteoretisk perspektiv på dramapædagogik kan nævnes Kjersti Hustvedts (2013) PhD afhandling Kontingente iaktakelser. Bidrag til en konstruktivistisk dramapedagogik.
} 
mennesker. De er ikke arbejdstagere i ordets egentlige forstand, men tager alligevel del i en dagligdag, hvor skole, privatliv, fritidsinteresser og arbejde indeholder flere roller. Senmodernitetens fragmenterede subjekt er en del af deres hverdag, også på de sociale medier.

Tiltrækningen mod det performative, som Kershaw argumenterer for og som Allern og Szatkowski beskriver, er fremdeles aktuel i en teater- og dramafaglig diskussion (Jf. Tynæs, 2013; Fogt og Fogh, 2015; Østern, Toivanen \& Viirret, 2017). Diskussionen har dog så langt opereret ud fra et teoretisk ståsted, men hvis man ser på skolefaget drama i denne kontekst, så vil en vending mod det performative også have didaktiske konsekvenser, måske endda epistemologiske. Både Szatkowski og Allern peger på dramaturgi som et væsentligt aspekt $\mathrm{i}$ forbindelse med at udforske det performative. Szatkowski bringer dramaturgien i spil som et analytisk redskab til at analysere kommunikation mellem mennesker, og hos Allern kan et grundigt kendskab til dramaturgisk tænkning hjælpe dramadidaktikeren til at bygge bro mellem teori og praksis (Allern, 2003, s. 424). Det kan således være relevant at dykke yderligere ned i begrebets betydning og undersøge dets relevans i en didaktisk kontekst.

\section{Dramaturgi i didaktisk kontekst}

Dramaturgibegrebet stammer fra teaterets verden og relateres til måden, instruktøren eller dramaturgen arbejder med en forestilling. Som fagområde eller teatervidenskabelig disciplin refereres der ofte til Aarhusmiljøet, som særligt i 1980'erne og 1990'erne har haft stor indflydelse på og bidraget til udviklingen af begrebet (Gladsø, Gjervan, Hovik \& Skagen, 2015; Szatkowski 1989, 1992; Szatkowski og Kjølner, 1991). I artiklen "Dramaturgisk analyse - et arbeidsredskap for ikke-naive instruktører" (1991), præsenterer Torunn Kjølner og Szatkowski fire dramaturgiske modeller; dramatisk, episk, simultan og metafiktiv. Hver model indeholder forskellige narrative principper, som monteres i fiktionslag. Et fiktionslag etableres gennem en stabil kombination mellem et rum (tid og sted), nogle figurer og en fabel (en fortælling) (Szatkowski, 1989, s. 59). I teatrets dramatiske form fremstår handlingen i en logisk forståelig rækkefølge, og det fiktive univers er tydelig etableret. I den episke form opereres der med mindst to fiktionslag, hvor teatret peger på sig selv som teater, blandt andet ved brug af distancerende greb. Fortællingen indeholder et overordnet princip. ${ }^{4}$ En simultan form kendetegnes ved, at indholdet er fragmentarisk monteret, og der findes ikke et samlende princip. Fiktionskontrakten er forvirrende, og publikum modtager mange forskellige budskaber på samme tid. Den fjerde og sidste model er den metafiktionelle form. I denne form opereres der også ud fra et fragmenteret montageprincip, men i modsætning til den simultane form, så kan der spores en fremadskridende handling. Den metafiktionelle form kan operere som et spil mellem de forskellige modeller.

\footnotetext{
${ }^{4}$ Et overodnet princip hos Bertolt Brecht er for eksempel politiske bevidsthed, som han ønsker at vække til live gennem sine forestillinger og sin dramatik.
} 
Hvis vi vender tilbage til det performative perspektiv, så er det særligt den simultane og metafiktionelle form, som kan føje sig ind under dette. Begge former benytter et mangefold af fortællerformer, som bryder med modernismens lineære tid. Metafiktionens anvendelse af ironi understreger fiktionens tvetydighed, og der ligger en senmoderne tænkning i den fragmenterede måde, den meningsskabende proces fremstilles på.

I Dramaturgi $i$ didaktisk kontekst (Østern, 2014) udforsker Anna-Lena Østern, hvordan dramaturgisk tænkning kan overføres til didaktisk virksomhed. Hendes mål er at bidrage til en fornyelse af undervisningsplanlægning og klasserumsledelse (Østern, 2014, s. 63). At tænke som en dramaturg i undervisningen handler om at overveje, hvilken historie man som lærer ønsker at fortælle. Svaret på spørgsmålet former undervisningsforløbet og har indflydelse på lærerens måde at iscenesætte et tema for eleverne. Alle fire dramaturgiske modeller indeholder retningslinjer eller værktøjer, som kan adapteres til lærerens praksis, men ligesom Allern, peger Østern på, at de repræsenterer forskellige syn på, hvordan forståelser kommer til syne (Østern, 2014, s. 60-61). Østern folder dramaturgibegrebet ud som et didaktisk værktøj, hvor de dramaturgiske modeller åbner op for eller inviterer til forskellige måder at arbejde med læring på. Udover at adaptere et begreb fra en teatervidenskabelig kontekst til en uddannelseskontekst, så er det også en måde at transformere et teoretisk koncept til didaktisk praksis (Jf. Allern, 2003, s. 424). Særligt simultandramaturgiens montageprincipper og dets fragmentariske sammensatte tekster nævnes som værende relevante i lyset af unges digitale hverdag:

Med bruk av montasjemodeller er man opptatt av å belyse ulike perspektiver gjennom å stille kontrasterende fragmenter ved siden av hverandre. Den simultane montasjen kan forme en spiralbevegelse gjennom at samme tematik belyses fra ulike perspektiver. Det kan bli en slags sirkeldramaturgi (Østern, 2014, s. 53-54).

Østern peger på unges brug af sociale medier som kommunikativ platform, og hvordan de udvikler høj kompetence $i$ at skabe montager og i at læse sammensatte tekster, når de interagerer på disse platforme.

Når jeg introducerer de dramaturgiske modeller i denne studie, er det ud fra en opfattelse af, at for at kunne undersøge, hvordan performative læringsrum opstår i krydsfeltet mellem dramadidaktik og sociale medier, forudsættes en forståelse af de narrative strukturer, som undervisningsforløbet \#ilive indeholder. Til at vejlede mig $i$ min analyse af \#ilives dramatiske form, bringes karakteristika fra henholdsvis den simultane og metafiktionelle dramaturgi med ind i undersøgelsen. Begge modeller er relevante, set i lyset af den forforståelse som ligger til grund for udviklingen af forløbet (Jf. Det performative samfund), samt parallellerne mellem simultandramaturgiens montageprincipper og unges brug af sociale medier.

\section{Undervisningsforløbet \#ilive}

Undervisningsforløbet er designet ud fra et ønske om at undersøge, hvordan sociale medier kan stimulere til dramadidaktisk fornyelse. Al kommunikation foregår på 
engelsk, og deltagernes mobiltelefoner er en aktiv del af forløbet. ${ }^{5}$ \#ilive udspiller sig i en dramasal med en spejlvæg, sorte tæpper langs væggene, lys- og lydudstyr, videoprojektorer og en lille scene. Forløbet blev gennemført fire gange med i alt 89 gymnasieelever fra første til tredje klasse. Eleverne er tilknyttet forskellige gymnasielinjer; to af klasserne tilhører "musik, dans og dramalinjen", én klasse "service og samferdsel" og den sidste en "almenfaglig" linje.

I en samlet indledende introduktion udenfor lokalet, får deltagerne udleveret en sort boks af forløbets assistent. Assistenten er iklædt sorte bukser, sort skjorte og en hvid sløjfe i håret. Kostumet er markeret, men alligevel forholdsvis neutralt og indeholder samme farvekombination, som den boks deltagerne får udleveret. \#ilive boksen indeholder diverse rekvisitter, blandt andet en QR-kode som deltagerne, ved hjælp af deres mobiltelefoner scanner, og de føres videre til en introduktionsvideo på det sociale medie Vimeo. ${ }^{6}$

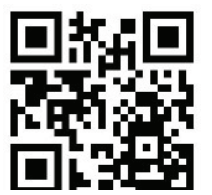

https://vimeo.com/133437785

I videoen introduceres værten, som er iklædt sorte bukser, sort skjorte, sort vest og en hvid butterfly. Ligesom assistentens kostume er værtens markeret, men på samme tid ganske neutral. Både assistenten og værten skal guide deltagerne igennem forløbets forskellige hændelser. Assistenten er forløbets igangsætter og katalysator. Efterfølgende tager hun del i forløbet siddende bag en mikserpult og styrer lyd, lys og videoprojektioner. Forløbets underliggende dramatiske fortællertråd iscenesættes, som et laboratorium omhandlende sociale medier. I introduktionsvideoen beskriver værten \#ilive som et "Laboratory. It's an experiment where I ask you to join me and explore the social media". ${ }^{7}$ De to spørgsmål som danner udgangspunkterne for de eksperimenter som laboratoriet indeholder, introduceres ligeledes i videoen; Who are you on the social media? How du you live with soial media? Deltagerne bliver afslutningsvis bedt om at tage en selfie og poste den på et socialt medie med hashtagen "\#ilive". Herefter går deltagerne ind i lokalet én efter én, hvor værten (i den fysiske virkelighed) tager imod dem, og de placeres på scenen. \#ilive består af 14 fragmenter eller leringshandelser. Hver læringshændelse har forskellige intentioner, som for eksempel; (1) udfordrer deltagerne til at løse forskellige opgaver, (2) tilfører deltagerne information, som de skal bruge i forløbet og (3) stimulerer til både individuelt og kollektivt arbejde. I modellen under (model 1) beskrives de 14 læringshændelser.

\footnotetext{
${ }^{5}$ For en grundigere indføring i udviklingsprojektet henvises til artiklen "Sociale medier - en ny scene for dramapædagogen" (Knudsen, 2015)

${ }^{6} \mathrm{QR}$-læser kan downloades via din appstore til både Android og Iphone.

${ }^{7}$ Citatet er hentet fra videoen "Welcome to \#ilive" på Vimeo, jf. QR-kode s. 9
} 


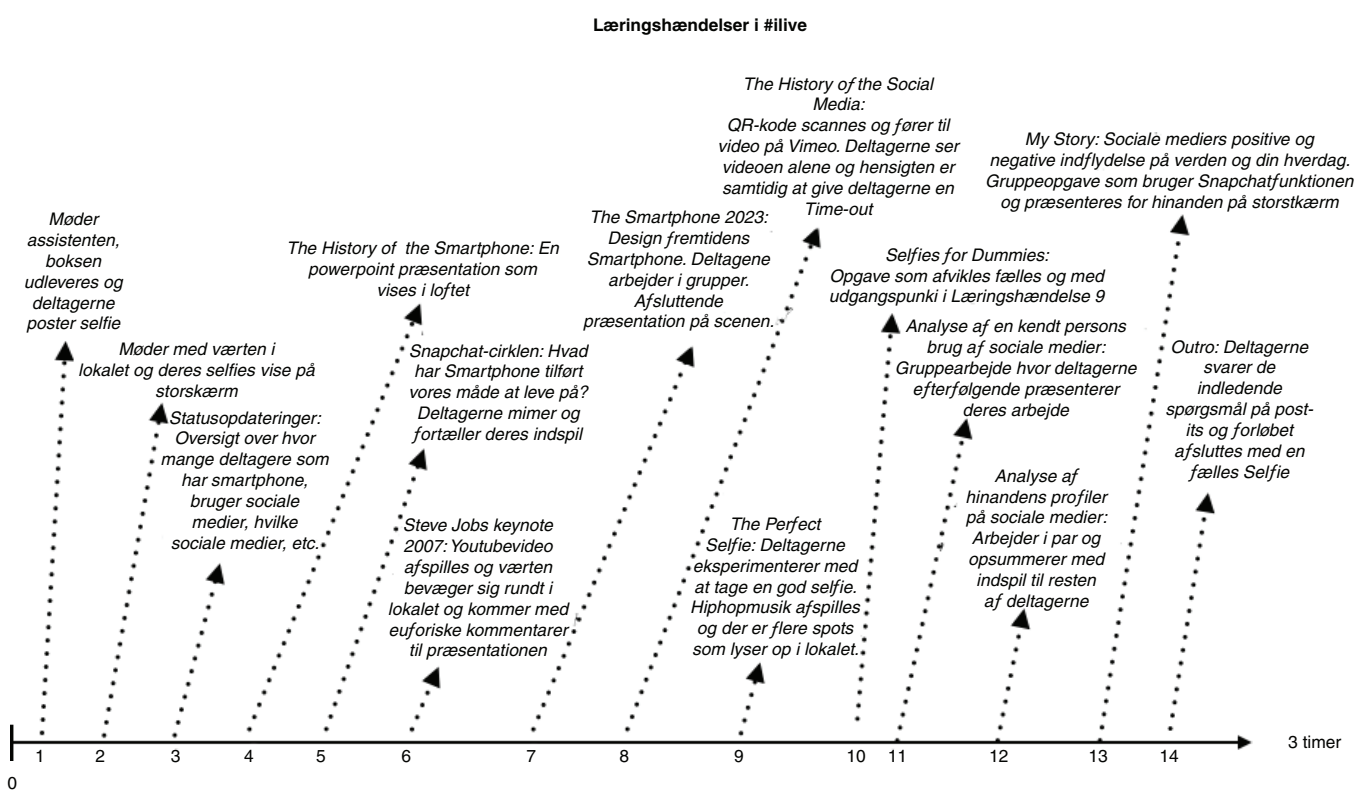

Model 1. Oversigt over de 14 læringshændelser som gennemføres i løbet af tre timer.

\section{Dramaturgisk analyse af \#ilive}

\#ilive udspiller sig $\mathrm{i}$ et stort lokale, som er rigget til med lys, videoprojekteringer på væggene, en lille scene og et musikanlæg. Assistenten sidder ved en mikserpult og styrer lyd, lys og videoprojektioner. Undervisningsforløbets narrative principper er monteret fragmentarisk, men indeholder alligevel en fremadskridende handling repræsenteret ved den tynde fortællertråd. I den indledende introduktion etableres et dramatisk fiktionslag, hvor deltagerne iscenesættes som deltagere i \#ilive. Forløbets fabel kan beskrives som et laboratorium, hvor deltagerne sammen med værten, skal udforske, hvem de er på de sociale medier, og hvordan de lever med de sociale medier. I et didaktisk perspektiv, kan samtlige læringshændelser defineres som hørende hjemme i en dramadidaktisk tradition. Der gøres brug af perspektivskifte $(7 / 12 / 13 / 14)^{8}$, rollespil $(7 / 8 / 10 / 14)$, scenisk fremførelse (8/14), mime og leg (6/10/14). De sociale medier fungerer både som forløbets tematiske omdrejningspunkt, samtidig med, at de tilfører undervisningen en ekstra scene eller platform for handling og kommunikation. De ekstra scener bringer potentielt nye didaktiske læringsrum i spil, og værten benytter sig aktivt af disse scenetyper flere gange i forløbet (2/3/5/7/9/10/12/13/14).

De 14 læringshændelser kan hver især monteres i forskellige fiktionslag (se model 2); (1) den tynde fortællertråd - \#ilive, laboratoriet om sociale medier. Det er forløbets assistent og vært, som er katalysatorerne i den fremadskridende handling, som

\footnotetext{
${ }^{8}$ Se model 1.
} 


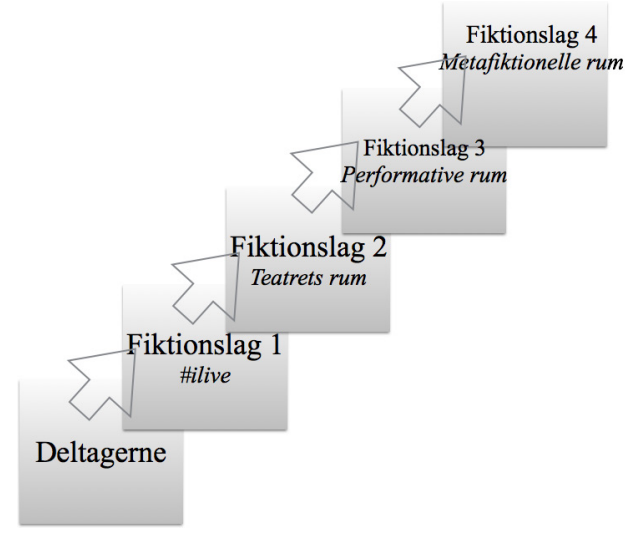

Model 2. Modellen viser, hvordan man dramaturgisk kan undersøge forløbet med udgangspunkt i de fire fiktionslag.

udspiller sig i dette fiktionslag. (2) Et abstrakt fiktionslag, som anvender tegn fra teateret til at understrege noget. For eksempel lys, lyd, kostumer osv. (3) Et performativt fiktionslag, hvor hændelsen transformeres til en selv-refleksiv handling. Dette fiktionslag etableres for eksempel, når deltagerne handler i en kontekst, hvor distinktionen mellem fiktion og virkelighed er diffus. $\mathrm{Og}(4)$ et metafiktionel fiktionslag hvor der forekommer en selvironisk distance fra deltagerne til projektet. I det metafiktionelle rum reflekterer, konstruerer og formidler deltagerne deres erfaringer.

Fiktionslagene etableres gennem forskellige måder at kombinere rum, figur og fabel på (Jf. Szatkowski, 1989, s. 59). I løbet af \#ilive manøvrerer deltagerne imellem fiktionslagene hjulpet af værten og assistenten. I modsætning til en dramatisk fortællerform, som kun opererer med ét fiktionslag, så skabes der et dialektisk forhold mellem fiktionslagene. Forløbet ligger som sådan tættest op ad en metafiktionel form med simultane indspil. Der er ikke et overodnet montageprincip, som de forskellige hændelser peger op imod, men i stedet en eksplorerende tilgang til spørgsmålene om; Hvem er du på de sociale medier, og Hvordan lever du med de sociale medier? I et overordnet montageprincip ville der allerede være et svar på spørgsmålene, og forløbets forskellige læringshændelser ville pege i den retning. Manglen på et overodnet montageprincip åbner op for at introducere forskellige perspektiver i fortællingen, og deltagerne bliver aktivt medskabende i den meningsskabende proces. Hvert fiktionslag indeholder et associationsrum, og det er deltagernes opgave at montere de forskelige perspektiver og derigennem skabe sin egen mening. I modellen nedenfor er de 14 læringshændelser monteret i de forskellige fiktionslag (se model 3).

Som det fremgår af modellen så peger læringshændelserne i forskellige retninger, og nogle læringshændelser opererer på flere fiktionslag samtidigt. I disse tilfælde bliver den meningsskabende proces endnu mere kompleks, da perspektiver monteres i flere fiktionslag simultant. Efterfølgende gives tre eksempler på læringshændelser, og hvordan deltagerne manøvrerer mellem de forskellige fiktionslag. Eksemplerne skelner ikke mellem de forskellige grupper, som deltog i \#ilive. Dette skyldes, at det 


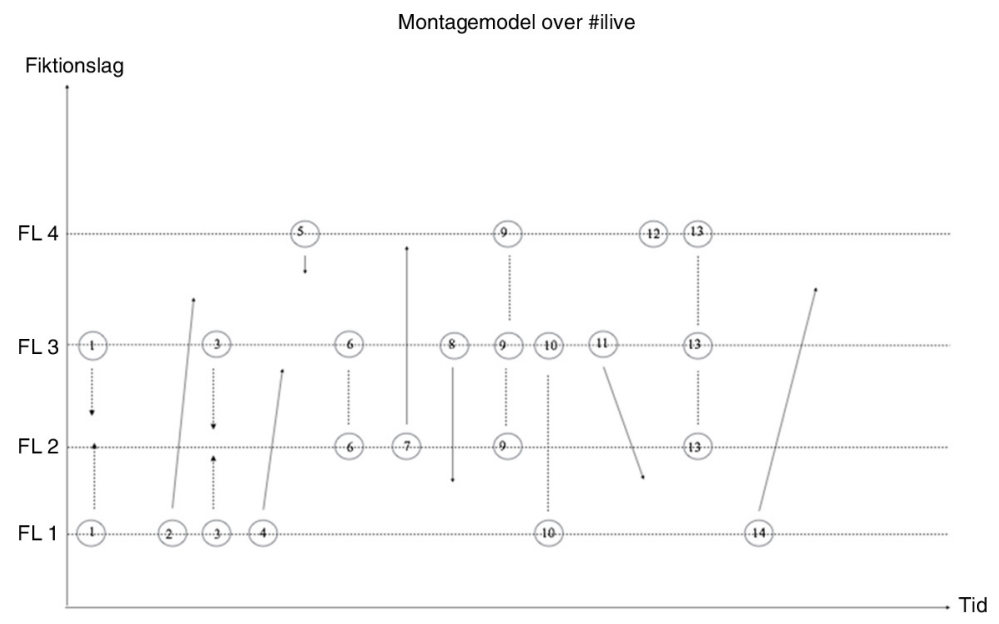

Model 3. Modellen illustrerer forløbets dramatiske form og hvilke fiktionslag, der er i spil i hver læringshændelse. Pilene peger i forskellige retninger og ikke mod et overordnet montageprincip. Læringshændelse 1, 3, 6, 9, 10 og 13 opererer på flere fiktionslag samtidigt.

ikke er deltagernes tilknytning til klassetrin og linjefag, som er i fokus i denne studie, men deres forskellige måder at manøvrere mellem fiktionslagene på.

\section{Læringshændelse 1 - "Welcome to \#ilive"}

http://makeagif.com/i/PG9L1u

I indledningssekvensen møder deltagerne assistenten og får udleveret \#ilive boksen. Boksen skaber forventninger om, hvad der skal til at ske; "Oh my God. This is so exciting" udbryder én af deltagerne og ser med spænding i blikket på de sorte bokse, som bliver udleveret. Andre deltagere tripper usikkert frem og tilbage. Nogle deltagere diskuterer, om de skal poste billedet på deres Instagram profil eller ikke, imens andre umiddelbart finder sammen i mindre grupper og poserer for mobilkameraet.

Indledningen er ment som forløbets anslag. Hensigten er at vække deltagernes nysgerrighed, skabe et spændingselement og give et indblik i, hvad forløbet kommer til at indeholde. Distinktionen mellem fiktion og virkelighed er ikke tydeligt defineret. Assistenten taler engelsk og er iklædt et enkelt kostume, men deltagerne kan selv justere niveauet af fiktion eller indlevelse. Dette kommer til udtryk i måden, de manøvrerer mellem de forskellige fiktionslag som hændelsen indeholder.

Billede 1 viser deltagerne i lokalet udenfor laboratoriet. De har åbnet \#ilive boksen og er i gang med at se velkomstvideoen. På dette tidspunkt befinder deltagerne sig i fiktionslag 1, hvor rum (lokalet udenfor laboratoriet), figur (assistentens rolle og deltagerrollen) og fabel (\#ilive) er tydeligt etableret. Men med introduktionen af selfieopgaven etableres et nyt fiktionslag (FL3). Når deltagerne poster selfien på Instagram, er det første gang i forløbet, at de interagerer med sociale medier, og kombinationen mellem rum, figur, fabel forandres. Tid og sted transformeres til også 


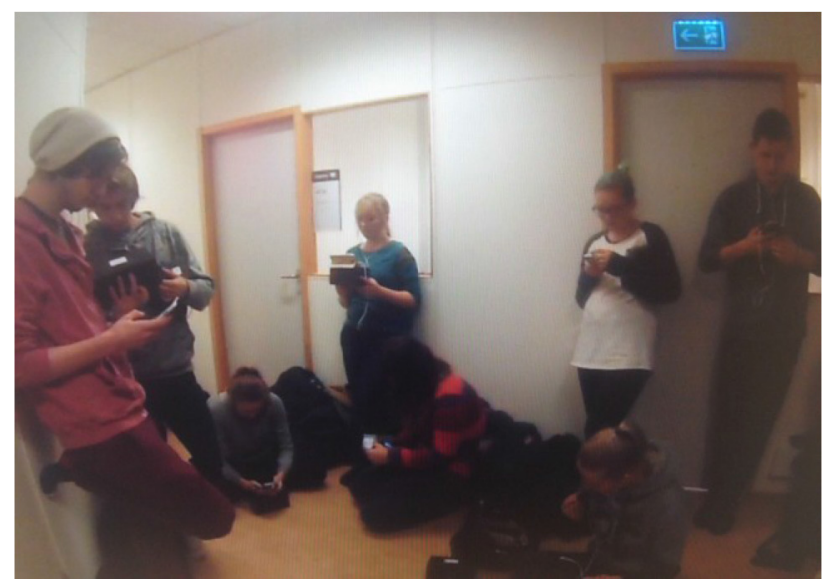

Billede 1. Deltagerne har åbnet \#ilive boksen (Screenshot fra \#ilive).

at inkludere de sociale mediers udvidede rum. Det vil sige, det er potentielt samtlige følgere af deltagerens Instagram- profil, og hvis profilen er offentlig, samtlige brugere på Instagram, som er vidner til at deltageren sætter sig selv på spil. Det betyder, at Deltagerrollen går fra at være en kollektivt defineret rolle til at blive et markeret individ/subjekt, som træder ind på den digitale scene $\mathrm{i}$ det øjeblik, selfien postes på Instagram. \#ilives tynde fortællertråd udvides fra at være en fortælling om et laboratorium omhandlende sociale medier til også at blive en del af deltagerens egen hverdagslige fortælling. Med introduktionen af de sociale medier transformeres Fabelen til også at omfatte subjektets performative fortælling.

Deltagerne håndterer overgangen fra fiktionslagene på forskellige måder. Nogle af deltagerne begynder at iklæde sig en karakter eller attitude. De tager for eksempel huer på, hætten op over hovedet og tilpasser en frisure. De poserer ved brug af for eksempel duckface og håndtegn. Eksemplet viser, hvordan deltagernes persona $\mathrm{i}$ mødet med det tredje fiktionslag transformeres, og deres performative subjekt træder frem. Andre deltagere håndterer det mere enkelt ved at tage et billede og skrive "skoleopgave" som tekst, før de poster det. Én af deltagerne udtrykker en ironisk distance til opgaven og udbryder "What filter should I use?!". Når deltagerne er færdige med selfieopgaven, vender de tilbage til den samme deltagerrolle, som de havde i fiktionslag 1.

Skiftet mellem fiktionslag 1 og 3 fordrer, at deltagerne tager et aktivt valg. Vil de udføre opgaven eller ikke? I en dramadidaktisk kontekst forudsætter den meningsskabende proces, at deltagerne accepterer fiktionens præmisser - det er essensen af fiktionskontrakten. Men som det fremgår af eksemplerne over, så medfører introduktionen af de sociale mediers udvidede rum, at niveauet af risiko øges betragteligt i fiktionslag 3. Denne risiko håndterer deltagerne på forskellige måder. De anvender forskellige strategier (kostume, ironisk distance og rationalitet) til at reducere risikoniveauet og bringer deres egen kultur med ind i måden at løse udfordringerne på. 
Læringshændelse 7 - "Smartphone anno 2023"

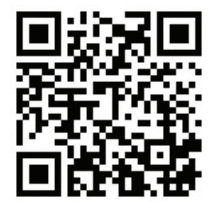

https://m.youtube.com/watch?v=Q3W58S29eSE

Før læringshændelsen har deltagerne set dele af ovenstående video på Youtube. I videoen præsenterer Steve Jobs den første iPhone, og præsentationen akkompagneres af musikgruppen Coldplay's "Viva La Vida". I \#ilive bevæger værten sig blandt deltagerne og skaber en bro mellem videoen og laboratoriets fiktive virkelighed. Han klapper og kommer med euforiske tilråb på lige linje med publikum, som er vidner til Jobs præsentation, og deltagerne begynder at gøre det samme. Efterfølgende iscenesættes deltagerne $\mathrm{i} \#$ \#ilive som designere og får til opgave at udvikle en prototype på en Smartphone i 2023. De deles ind i mindre grupper og får besked på, at de skal finde et navn på produktet, udvikle en produktbeskrivelse samt indøve en præsentation. Afslutningsvis skal grupperne lancere deres produkt for hinanden. Præsentationen foregår på en scene, og Coldplay's "Viva La Vida" fungerer som musikalsk baggrund i overgangen mellem fremføringerne. Det er ikke sikkert, at deltagerne lægger mærke til, at det er den samme musik, som afspilles. Musikken er ment som et stemningsskabende element, samtidig med, at det har en dramaturgisk funktion, da to læringshændelser væves sammen musikalsk.

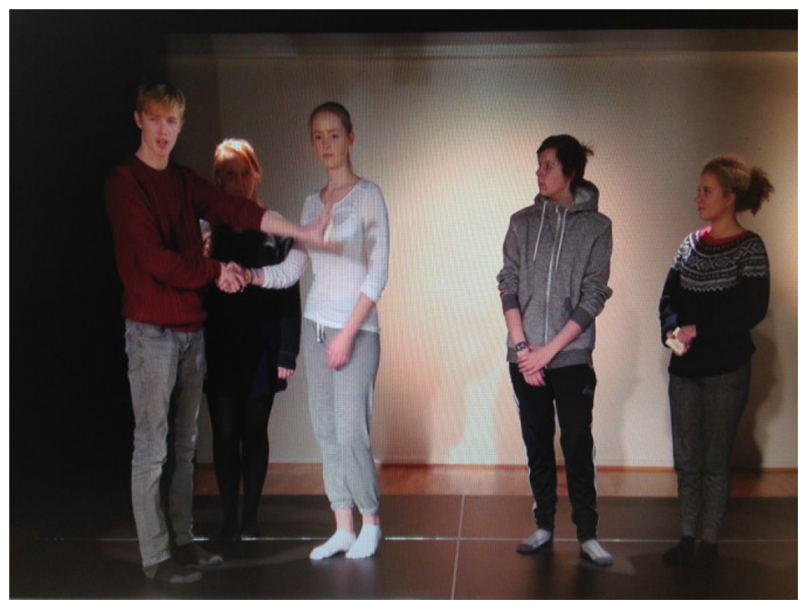

Billede 2. Præsentation af "Q"- et forslag til en Smartphone i 2023 (Screenshot fra \#ilive).

Ovenfor præsenteres "Q". Deltagerne har ikke noget kostume på, men deres kropsholdning og måden de taler på, forstærker indtrykket af, at de fremstiller sig selv som designere. På billedet introducerer designerne én af Q’s egenskaber. Når man hilser på en person, reagerer "q-signaler" i hånden og en profil "popper" op på en virtuel skærm ved siden af personen. På skærmen fremgår det, om man har fælles 
bekendtskaber, alder, interesser, uddannelse og civilstatus. På denne måde kan man hurtigt og effektivt finde ud af, om man har noget tilfælles. Læringshændelsen udspiller sig i et fremtidsscenarie og indeholder en tydelig fiktionskontrakt, som understreges i deltagernes rolle som designere. Deltagerne manøvrerer her i et abstrakt fiktionslag (FL2), hvor teatrets tegn anvendes til at understrege deltagernes produkt gennem musik, lys, tempoforandringer, scenografi og roller. Præsentationerne foregår både på norsk og på engelsk, og den samme euforiske stemning, som blev skabt under videopræsentationen, bringes med ind i deltagernes fremførelse. Deltagerne bruger ofte samme formidlingsstil som Steve Jobs, dog nogle mere karikerede end andre. Niveauet af euforisk stemning samt deltagernes måde at formidle på, indeholder i nogle tilfælde større grader af ironi eller sarkasme. Der kan være flere grunde til, at disse situationer opstår; (1) fiktionskontrakten har ikke været godt nok etableret før deltagernes arbejde eller, (2) at deltagernes usikkerhed resulterer i, at niveauet af indlevelse reduceres. Det kan også tolkes som, (3) at deltagerne er i en transformationsproces, hvor de konstruerer mening og konstant udforsker forskellige perspektiver, som monteres i fiktionslagene. Szatkowski beskriver denne aktivitet som vævning. Aktiviteten forekommer, når en forestilling indeholder billeder (eller perspektiver), som er så komplekse, at de må læses som mange, samtidige billeder lagt oven på hinanden; "Billedet er sin egen historie, men det binder sig også sammen med det foregående og efterfølgende" (Szatkowski, 1989, s. 78). I \#ilive opstår vævningsaktiviteten i de situationer, hvor distinktionen mellem fiktion og virkelighed reduceres, og deltagernes præsentation bliver mere selv-refleksive. Læringshændelsen opererer fremdeles i fiktionslag 2, men deltagerne bevæger sig på tværs af fiktionslag 2, 3 og 4. Hvert fiktionslag indeholder et associationsrum, og det er deltagernes selv, som monterer de forskelige perspektiver, og derigennem skaber sin egen mening. Deltagernes måde at håndtere overgangene mellem fiktionslagene vidner om, at \#ilive som dramadidaktisk forløb åbner op for, at deltagerne kan håndterer risiko og konstruere mening på forskellige måder.

\section{Læringshændelse 9 - "The Perfect Selfie"}

Deltagerne får til opgave at eksperimentere med at tage den perfekte selfie. Hiphopmusik strømmer ud af højtalerne, og der sker et markant skifte i lyset. Nogle deltagere bruger lokalets spejlside andre farvede lyskilder fra loftet. Denne læringshændelse opererer med tre fiktionslag, og kombinationen mellem rum, fabel og figur forandres i hvert fiktionslag. Det abstrakte fiktionslag (FL2) etableres ved hjælp af tegn fra teateret, som bidrager med at skabe en ramme omkring opgaven og deltagerne. Læringshændelsens legende element forstærker distinktionen mellem fiktion og virkelighed samt forholdet mellem rolle og person. Det metafiktionelle rum (FL4) etableres gennem en form for selvironiske distance til opgaven. Selvironien kommer til udtryk på flere måder; (1) når de ser og kommenterer hinandens billeder, 


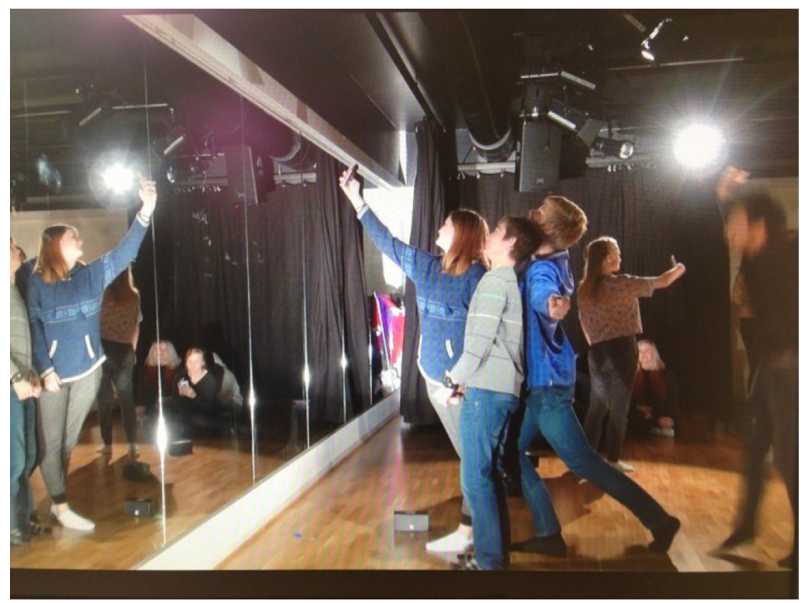

Billede 3. Deltagernes performative leg med den perfekte selfie. (Screenshot fra \#ilive)

(2) når de ler med og af hinanden, og (3) som det fremgår af billedet under, når de udfører overdrevene kropslige stillinger eller ansigtsudtryk.

I fiktionslag 4 er der ikke nødvendigvis et tydeligt skel mellem fiktion og virkelighed, men deltagernes ironiske distance bringes med ind i deres måde at håndtere opgaven på. Distancen bidrager til at reducere niveauet af risiko samt skabe en tryghed hos deltagerne. Læringshændelsen knytter sig direkte til situationer som deltagerne genkender fra deres hverdag, men i \#ilives iscenesættelse transformeres de til noget mere eller noget andet end hverdagslige situationer. Den hverdagslige leg bliver til en performativ leg. Performativ på den måde, at deltagerne deltager i en hændelse, som er bevidst det performative, når deltagerne gennem fremførelsen gør sine egne handlinger fuldstændige (Jf. Allern 2003, s. 314). Det tredje og sidste fiktionslag opererer således i det performative rum (FL3). Fiktionslaget etableres, når deltagerne indgår i en selv-refleksiv leg med kamera og hinanden. I dette fiktionslag er der ikke et tydeligt skel mellem fiktion og virkelighed. Deltagerne eksperimenterer med teknik, stil og forskellige måder at posere på: "Decide your charachter. Like, do you wan't to be a fuck boy, pretty girl, cute girl, stripper, player. Find your pose", siger én af deltagerne og peger her på potentielle roller, som det performative subjekt (personen) kan udforske på de sociale medier. Af andre roller nævnes; the comedian, the careful one, the communicator, the observer, the happy one, m.fl. Nogle deltagere påpeger, at de er sig selv, og andre mener, at det varierer alt efter, hvilket socialt medie man bruger. For nogle af deltagerne bliver de forskellige roller vejledende for deres performative subjekt, og måden de iscenesætter sig selv på. For andre skaber rollerne en falsk overflade. Uanset strategi, så vidner udsagnene om, at der i de sociale mediers dobbelthed (eller rum), ligger en mulighed for at udforske sig selv. En dobbelthed som har paralleller til dramadidaktikkens rollespil og andre måder at undersøge eksistentielle spørgsmål på. 


\section{Når "den anden" er dig selv - person/rolle distinktionen på de sociale medier}

\#ilive tager udgangspunkt i to spørgsmål; Hvem er du på de sociale medier og Hvordan lever $d u$ med de sociale medier? Det er som sådan eksistentielle spørgsmål, som undersøges $\mathrm{i}$ en dramadidaktisk kontekst, men som den dramaturgiske analyse af \#ilive viser, så bringer de performative læringsrum nogle andre spilleregler med ind $\mathrm{i}$ det didaktiske arbejde. I stedet for at spille en "anden" person, transformeres den "anden" til dig selv på de sociale medier - imens du er den, du er i det sociale rum. Der er tale om en form for de-individualisering, vi er os selv sammen med andre, og distancen til sig selv ligger et sted i den overgang. Szatkowskis distinktion mellem person og rolle kan fungere som et udgangspunkt for at undersøge den komplekse kommunikation, som opstår i de performative læringsrum. Ifølge Szatkowski er det først, når skelnen mellem person og rolle er indført, at det giver mening, at det enkelte menneske kan identificere sig som person og samtidig orientere sig i forhold til forskellige roller (Szatkowski, 2011, s. 114-115). De sociale mediers rolleregister indeholder roller, som kan udføres af mange, og som samtidig vejleder brugernes adfærd. Hvad enten du vælger The Cute Girl, The Player, The Stripper eller The Comedian, så skitseres en potentiel adfærd. Spørgsmålet er, hvilke værdier der kan ligge bag rollen, og hvilke typer adfærd, samt social accept som sikres, hvis man følger dens program? De performative læringsrum tilfører dramadidaktikken en genre, hvor denne kompleksitet kan udforskes. I et kontinuerligt sammenspil med teaterets virkemidler, multimedier, sociale medier og dramaturgi konstrueres både digitale og analoge scener, som åbner op for interaktion og refleksion. På disse scener skabes sociale rum, hvor gruppeindivider udspiller eksistentielle spørgsmål i komplekse kommunikative mønstrer. En kompleksitet, som opererer på et lignende niveau, som den deltagerne benytter, eller udsættes for til dagligt (Jf. Østern, 2014, s. 53-54). I de performative læringsrum er der et mangefold af roller, fiktionslag og narrativer, som kan monteres på forskellige måder. Hvert fiktionslag indeholder potentielle rum for læring, og de sociale mediers udvidede forhold til rum, figur og fabel ekspanderer læringsrummene yderligere. Dobbeltheden på de social medier, og den rolleleg de åbner op for, kan undersøges nærmere, rammesat af den samme diffuse distinktion mellem fiktion og virkelighed, som de genkender fra deres egen hverdag.

\section{Performative læringsrum i didaktisk kontekst}

I artiklen har jeg flere gange peget på den kompleksitet, som opstår i forbindelse med at implementere performative læringsrum i en didaktisk kontekst. Det skal alligevel ikke afholde skolen og læreren fra at forsøge. I de performative læringsrum får læreren mulighed for at møde eleverne i sociale rum, som åbner op for digitale og analoge samtaler. Kommunikationen er kompleks, men det er en kompleksitet, som har paralleller til den måde, eleverne kommunikerer til dagligt (Østern, 2014, s. 5354) og som ræsonnerer med senmodernitetens syn på subjekt og erkendelse. De 
sociale medier er ikke i sig selv performative læringsrum. Det performative fordrer blandt andet en selvrefleksiv iscenesættelse (Allern, 2003, s. 314). Dramafagets kendskab til dramaturgi, teatrets virkemidler og fiktion kan bidrage til at udvikle didaktiske greb og derigennem skabe performative læringsrum, som kan implementeres $\mathrm{i}$ undervisningen.

I de performative læringsrum udfordres dramadidaktik. Den diffuse distinktion mellem person og rolle reducerer fiktionskontraktens beskyttende virkning (Szatkowski, 2011, s. 119). Teatrets distancerende virkemidler bliver statister i en didaktik, hvor selvrefleksive læringshændelser og performative subjekter spiller hovedrollen. De performative læringsrum tager udgangspunkt i simultan og metafiktionel dramaturgi og bringer deres måde at skabe mening på med ind $\mathrm{i}$ kundskabsprocessen. Det stiller krav til både dramadidaktikeren og til deltagerne, da de skal være villige til at iscenesætte sig selv og fortællingerne på nye måder. Det dialektiske forhold mellem fiktion og virkelighed medfører dermed risici for begge parter. I \#ilive håndteres denne risici med udgangspunkt i de tilstedeværendes egen kultur som omdrejningspunkt og som strategi til at undersøge og udforske eksistentielle spørgsmål som; Hvem er du på de sociale medier og Hvordan lever du med de sociale medier?

I krydsfeltet mellem dramadidaktik og sociale medier inviteres læreren ind i elevernes daglige sociale rum. Dramafagets kendskab til teatrets tegn og dramadidaktikerens kendskab til at arbejde med flere fiktionslag, kan hjælpe skolen med at etablere læringsrum, hvor de sociale medier er mere end et forstyrrende element. I stedet transformeres de sociale medier til digitale scener, hvorpå skolens rolle (i samfundet) kan gå i dialog med elevernes performative subjekter. Sammen kan de udforske den kompleksitet, som råder i en globaliseret og medieret verden.

\section{References}

Allern, T. H. (2003). Drama og erkjennelse. En undersøkelse av forholdet mellom dramaturgi og epistemologi i drama og dramapedagogikk. Trondheim: NTNU, Insttitutt for kunst- og medievitenskap (Diss.).

Austin, J. L. (1992). How to Do Things with Words. The William fames Lectures Delivered at Harvard University in 1955. Oxford: Oxford University Press.

Butler, J. (1999). Gender Trouble, Feminism and the Subversion of Identity. New York: Routledge.

Fischer-Lichte, E. (2008). The Transformative Power of Performance, S. I. Jain(trans.). London/New York: Routledge.

Fischer-Lichte, E. (2014). The Routledge Introduction to Theatre and Performance Studies. London/New York: Routledge.

Fogt, J. \& Fogh, C. (2015). The postdramatic turn - recasting the dramatic curriculum. The European fournal of Social \& Behavioural Sciences, 14(3), s. 1915-1928.

Gladsø, S., Gjervan, E.K., Hovik, L., \& Skagen, A. (2015). Dramaturgi - forestillinger om teater. Oslo: Universitetsforlaget.

Hustvedt, K. (2013). Kontingente iaktakelser. Bidrag til en konstruktivistisk dramapedagogik. Aarhus Universitet: Institut for Æstetik og Kommunikation (Diss.).

Kershaw, B. (1999). The Radical in Performance: between Brecht and Baudrillard. London: Routledge.

Kjølner, T. \& Szatkowski, J. (1991). Dramaturgisk analyse for ikke-naive regissører. I H. Reistad (Red.), Regikunst (s. 122-132). Oslo: Tell forlag. 
Knudsen, K. N. (2015). Sociale medier - en ny scene for dramapædagogen. Drama Nordisk Dramapedagogisk Fournal, nr 3, s. 46-50.

Szatkowski, J. (1989). Dramaturgiske modeller - om dramaturgisk tekstanalyse. I E.E. Christoffersen, T. Kjølner \& J. Szatkowski, Dramaturgisk analyse. En antologi (s. 9-92). Århus: Universitetet i Aarhus, Institutt for dramaturgi. (Aktuelle teaterproblemer, 24).

Szatkowski, J. (1992). Et dramaturgisk vende. Perspektiv for teatervidenskaben. Dramaturgiske modeller og forestillingsanalyse. BUNT. Bulletin for nordiske teaterforskere, 10, s. $28-52$.

Szatkowski, J. (2011). Person og rolle. Peripeti tidsskrift for dramaturgiske studier, særnummer 2011, $162-175$.

Tynæs, A. (2013). Performativ danning - kollektive transformasjonsprosesser. I K. M. Heggstad, S. A. Eriksson \& B. Rasmussen (Red.), Teater som danning (s. 162-175). Bergen: Fagbokforlaget.

Østern, A.L. (2014). Dramaturgi i didaktisk kontekst. Bergen: Fagbokforlaget.

Østern, A.L., Toivanen, T. \& Viirret, T.L. (2017). Drama Boreale perspectives on drama education in Finland and Norway - Struggling for a place in the educational system. I E. Kimonen \& R. Nevalainen (Red.). Reforming Teaching and Teacher Education: Bright Prospects for Active Schools. (s. 169-195). Rotterdam: Sense. 